\title{
Efficiency and legitimacy in collaborative public management: mapping inter-local agreements in England using social network analysis
}

\author{
Ruth Dixon and Thomas Elston \\ Blavatnik School of Government \\ University of Oxford
}

\begin{abstract}
English councils have long aspired to be "self-sufficient," providing services within single jurisdictions with limited inter-local collaboration. However, by 2017 almost all local councils $(97 \%)$ participated in one or more frontline or back-office "shared service" involving 338 distinct partnerships. We analyse this new-found enthusiasm for inter-council collaboration by performing exploratory social network analysis on organizational and financial data for all 353 English councils. We examine factors predicting collaboration and the characteristics of the service networks that result, focusing on resource, organizational and political considerations. Propensity to collaborate was found to be unpredictable, but partner choice was rational, driven by geographical proximity and similarity in organizational and resource characteristics. We argue that, according to the institutional theory of organizations, both efficiency and legitimacy influenced reform choices, and the risks of collaboration were mitigated by careful partner selection. We highlight implications for future quantitative research into symbolic (non-instrumental) forms of collaboration.
\end{abstract}

\section{Key words}

Collaboration; efficiency; inter-local agreements; local government; shared services

\section{Acknowledgement}

This research was funded by Oxford University's John Fell Fund (Grant No. 171/311) and the British Academy and Leverhulme Trust (Grant No. SG160949). 
"Why ... is there such unyielding local resistance to voluntary joint schemes? ... In the first place, [councils] are afraid that entrance to a joint scheme will be a confession of the need for a larger area, and will risk annexation of their own.... [Secondly,] if they enter into a joint arrangement, they will be admitting the need for the service [and] new expenditure. Thirdly, there is sheer infatuation with the idea of their own independence, and jealousy of their neighbours. Such jealously may seem ... improbable... It, nevertheless, exists."

- Herman Finer, 1933, English Local Government

\section{INTRODUCTION}

Shared services, or "inter-local agreements," are a common mechanism for delivering local public services in many countries (Bel \& Warner, 2016; Teles \& Swianiewicz, 2018). The stated justification is that coordination problems and scale diseconomies can be overcome by councils working in partnership to provide services across their separate jurisdictions (Elston et al., 2018; Feiock, 2007; Ostrom et al., 1961). But not in England. Here, joint provision of services by local authorities working collaboratively has not been widely practised (Hulst \& van Montfort, 2012; Kelly, 2007). As long ago as the 1930s - the "golden age" of English local government, when council responsibilities were plentiful and their freedom from Whitehall considerable - Herman Finer attributed this lack of inter-council collaboration to the "sheer infatuation with the idea of their own independence" (see epigraph above). Many decades later, Stewart (2000, p.67) similarly observed a continuing aspiration for "selfsufficiency" and persistent "scepticism about joint working." Somewhat ironically, therefore, it has been through the imposition of far more disempowering reforms - to council size and responsibilities - that central government has sought to tackle local fragmentation (John, 2010). Such "restructuring" of local government became "an addictive habit to which British government ministers and civil servants are peculiarly prone" (Elcock et al., 2010, p.331), whereas joint working was simply "not taken seriously" (Stewart, 2000, p.267).

But it appears no longer. The Conservative-Liberal Democrat coalition government elected in 2010 ruled out further restructuring of councils, but enthused about shared services. "I am not at all interested in the structure of local government" said Eric Pickles while 
shadow Secretary of State for Local Government, "but we will expect councils to ... cooperate and work together" (Conservative Home, 2008). His wish was granted. By 2017 more than 97 per cent of councils participated in at least one inter-council collaboration, providing services such as social care, waste collection, libraries and back-office administration. Our purpose in this article is to understand how this significant and "unEnglish" collaboration has been implemented, and consider the motivation behind such longresisted reforms, focusing on differences between organizational efficiency and organizational legitimacy.

Using social network analysis (Borgatti et al., 2018), we investigate drivers of intercouncil collaboration and the characteristics of the resulting networks, focusing on resource, organizational and political considerations. We also test for differences relating to political salience and partnership size. Our results indicate few consistent predictors of collaboration. However, partner selection is important, and is driven mainly by geographical proximity and similarities in organizational characteristics and resource requirements. We interpret this inconsistency in our ability to explain council choices about reform adoption and partner selection as evidence of collaboration being employed as much for legitimacy-enhancing as for efficiency purposes, supporting recent work by Dickinson and Sullivan (2014), Jacobsen (2015) and others on the "cultural" rather than "instrumental" reasons to collaborate.

Combined with insights from the institutional theory of organizations (Meyer \& Rowan, 1977; Scott, 2014), which highlighted the trade-offs that organizations often face between efficiency and legitimacy, our findings suggest several empirical markers by which future quantitative research can detect when acceptance among stakeholders is supplementing or supplanting organizational efficiency as a motivation for collaboration.

The structure of the paper is as follows. First, we identify the main factors that could influence implementation of collaborative reforms from an instrumental, or "goal 
attainment," point of view, as well as the alternative explanation relating to organizational legitimacy. We then describe our empirical case, methods and results. Finally, we present our interpretation based on institutional theory, and its implications for future research.

\section{CONSIDERATIONS IN SHARED SERVICE DESIGN}

Organization theory and existing research on the drivers of inter-local collaboration suggest three main factors that may have influenced shared service adoption in England, concerning resources, organizational characteristics, and politics. To these we add a fourth, still nascent, perspective that rationalizes collaboration by its potential to enhance legitimacy.

\section{Resource considerations}

Availability of resources to deliver organizational objectives is a key consideration for any organization (Lee \& Whitford, 2012), and is known to affect inter-organization relations (Barney \& Clark, 2007). Abundance of, or deficiency in, the human, financial and technological resources necessary to deliver council objectives may influence both the motivation to collaborate inter-locally and the ability to do so successfully. The period of austerity after the 2008 financial crisis hit English local government particularly hard, and was one of the main publicly stated reasons for cost-saving reforms in the past decade.

\section{Council characteristics}

Resource availability often correlates with organizational size, since quantity and quality of resources depends on investment levels and/or establishing a "critical mass." Thus, smaller councils may be especially keen to collaborate. Research in the USA tends to find inter-local cooperation to be negatively related to council population size (Carr et al., 2009; Shrestha \& Feiock, 2011). In Europe, some studies concur (Bel et al., 2014; Eythórsson et al., 2018) while others disagree (Puey et al., 2018). 
Resource deficiencies might be also be related to other characteristics such as local labour market conditions. Those English councils identified for possible amalgamation in the late 2000 s might have experienced such difficulties, in which case those that ultimately survived the threat of abolition might pursue shared services instead (Bello et al., 2018). Indeed, inter-council cooperation often develops as an alternative to amalgamation, as evidenced by its significance in countries uninterested in mergers, like France (Teles \& Swianiewicz, 2018), and its decline after amalgamation has occurred, as in Germany (Norton, 1994).

Councils in areas of greatest social need may also experience higher demand for specialist resources, making them more prone to collaboration. Several studies relate the propensity to cooperate to such demographic characteristics (Joassart-Marcelli \& Musso, 2005; LeRoux \& Carr, 2007; although see Krueger \& McGuire, 2005 for contrary evidence).

\section{Financial health}

Lack of finance is a particularly challenging resource deficit, preventing the acquisition of other performance-enhancing capabilities (Lee \& Whitford, 2012). This provides strong motivation for cooperation. Yet, internationally, there is mixed evidence about the importance of financial resources. Fiscal burden does not predict cooperation in Spain (Bel, et al., 2014) or Switzerland (Steiner, 2003). In the US, Joassart-Marcelli and Musso (2005) and Kwon et al. (2014) find a positive association between fiscal stress and cooperation, while Morgan and Hirlinger (1991) and LeRoux et al. (2010) report little or no relation. LeRoux and Carr (2007) find variation across service areas. Although shared services are widely expected to produce cashable savings, poor financial health poses a barrier to wouldbe collaborators, since partnering requires upfront investment. Hefetz and Warner (2012, p.307), for instance, find that fiscal stress inhibits cooperation. Furthermore, authorities in 
poor financial health might be regarded as liabilities by prospective partners, and thus struggle to secure cooperation opportunities.

\section{Administrative capacity}

Lastly among the resource considerations, collaboration requires spare administrative capacity. "Successful adoption of innovations depends largely on the leadership, support, and coordination [that] managers provide" (Damanpour, 1991, p.559). Although councils with larger administrative workforces are often criticized as bloated, they may have greater capacity for reform (Eckersley \& Tobin, 2019). McGuire and Silva (2010) demonstrate this in the case of local emergency management collaboration in the US.

\section{Organizational considerations}

Formal organizations integrate diverse resources to achieve objectives (March \& Simon, 1993). Coordination between departments is essential but creates administrative overheads; hence, managers strive to achieve tolerable levels of coordination at minimum cost. Involvement of resources beyond the organizational boundary, as occurs with the delegation of work between shared service partners, is especially challenging. External actors are inert to the most efficient means of coordination - the unified command structure (Chisholm, 1989). Alternative coordination mechanisms thus become necessary, typically involving lateral relationships among separate workforces guided by a sense of common purpose rather than top-down executive authority. How such "network" coordination unfolds may depend on partnership size. In the private sector, evidence suggests that informal coordination arrangements are most effective for two-member (dyadic) alliances, with multi-member collaborations requiring more formal controls (García-Canal et al., 2003). Either way, external collaboration increases the bargaining time required to reach decisions. Thus, "the potential costs of coordination are an important factor in predisposing an organization to [collaborate or not]" (Alexander, 1995, p.18). 


\section{Similarity}

One way for councils to avoid excessive coordination costs is to partner with "similar" councils - that is, to demonstrate "homophily" (defined below). Alter and Hage (1993, p.242) maintain that: "it is much harder to get a set of diverse agencies to work together than it is to manage a set of similar organizations." Councils that are alike may experience common challenges, and interpret them comparably, reducing the need for information exchange and bargaining time. Homophily might occur on a number of dimensions, including: council type, which predicts service responsibilities and basic geographical attributes; population characteristics, which signal potential compatibility in citizen needs and preferences (Feiock, 2007); and location, because geographically proximate councils may (perceive that they) experience common challenges (Alonso et al., 2016), share a regional identity that facilitates a sense of mutual endeavor (Tomaney \& Ward, 2000), or be able to share physical resources and meet regularly.

International research on inter-local collaboration has indeed identified homophily between partnering organizations in terms of socio-economic characteristics (Dye et al., 1963), region (Klok et al., 2018), and political character (see below). LeRoux, et al. (2010) find that participation of bureaucrats in regional associations increases the likelihood of their councils forming inter-local agreements, although LeRoux and Carr (2007) and Kwon, et al. (2014) downplay this social-networking effect.

\section{Partner familiarity}

Partnering with organizations about which there is greater knowledge regarding motivations, preferences and abilities should also limit coordination costs (Gulati, 1995). Familiarity lessens the chance of "unwelcome surprises," facilitating credible commitments and reducing transaction costs. Again, councils will be more familiar with near neighbours than distant authorities (Alonso, et al., 2016). Those operating in a two-tier structure will have already 
worked with others within the county boundary on county-wide matters like transportation (Kelly, 2007). And those in the same English region (of which there are nine) will similarly have interacted through various (now defunct) regional fora.

\section{Structural complexity}

A third strategy for minimizing coordination costs is to select partners with low internal coordination challenges. Since inter-local cooperation depends not only on reaching agreement between partners, but also on implementing agreed policies within each council's departments, those experiencing more acute departmentalism - or high "structural complexity" (Dooley, 2002) - may make less reliable partners. For instance, McGuire and Silva (2010) find that low agency complexity facilitates collaboration.

\section{Political considerations}

A third set of considerations relates to English councils' status as institutions of local government, not simply local administration (Stewart, 2000). Local authorities are overseen by elected representatives accountable to the public and influenced by various local and national party-political processes. This could affect inter-local cooperation significantly.

\section{Partisanship}

Councils more sympathetic to the national government's ideology and policies may be more willing to pursue centrally-advocated reforms. In the 1980s, for instance, "hard-left" councils resisted Margaret Thatcher's right-wing policies (Wilson \& Game, 2011). Councillors may also choose to cooperate with others of similar political outlook, whether because of agreement on objectives or for party solidarity. Leach and Game (1991, p.169) found "the dominance of the Labour Party in five of the six areas was unquestionably a key factor" in facilitating lower-tier cooperation after the abolition of metropolitan county councils. International experience also consistently indicates that "political homophily" facilitates inter-local collaboration (Bel, et al., 2014; Gerber et al., 2013; Song et al., 2018). 


\section{Electoral stability}

Democratic events may change councils' political control and preferences about joint working, destabilizing partnerships and wasting investments (Feiock, 2007). Electoral instability may deter prospective partners; and "hung" councils, where no party is in overall control, are less likely to collaborate, since time spent "brokering internal deals within and between parties ... impede[s] externally responsive and speedy decision-making" (Gains et al., 2009, p.84).

\section{Political salience}

Finally, political support for inter-local working may vary by service area. Some council activities affect large and vocal constituencies and attract significant media attention. As Ferris and Graddy (1986, p.334) explain: "to the extent that a service constituency is an important voting component of the local government, we would expect less contracting out in that service." Experience with metropolitan cooperation in England confirms that this "tend $[\mathrm{s}]$ to be on peripheral and relatively noncontroversial matters, and not on matters of significance" (Norris, 2001, p.540). International evidence also supports this proposition (Hefetz \& Warner, 2012; although see Eythórsson, et al., 2018).

\section{Collaboration and legitimacy}

The aforementioned explanations of inter-council collaboration, especially those relating to resources and organizational characteristics, imply that joint working is driven by instrumental concerns to solve observable organizational problems and thereby increase goal attainment and organizational efficiency. Recently, this has been criticized as overly-rational (Dickinson \& Sullivan, 2014; Sullivan et al., 2013), reawakening an older school of thought in organization theory that recognizes the diverse and often non-technical reasons for establishing inter-organizational relations (Oliver, 1990). In particular, this literature suggests that, regardless of its effect on public service efficiency or effectiveness, 
collaboration occurs because such behaviour is well-regarded by stakeholders whose opinion of the organization matters. "To argue for the importance of partnerships is like arguing for 'mother love and apple pie,"” writes McLaughlin (2004, p.103). "Partnership working has an inherently positive moral feel about it and it has become almost heretical to question its integrity." By adhering to such widely-held expectations about "appropriate" behaviour, organizations enhance their legitimacy. Collaboration is thus about "confirming ... allegiance to a set of values and norms," rather than to fulfil some immediate, instrumental purpose (Sullivan, et al., 2013, p.125).

Case-study research on symbolic uses of inter-municipal collaboration in Norway (Jacobsen, 2015) and healthcare partnerships in Canada (Rodríguez et al., 2007) offers empirical support for this this alternative explanation. But scholars have yet to identify conditions in which legitimacy is likely most to supplement or replace efficiency as a motivation for joint working, nor the empirical markers that could help to detect this in quantitative analysis. We return to these questions in the discussion section.

\section{ENGLISH LOCAL GOVERNMENT:}

\section{STRUCTURE, SIZISM AND SELF-SUFFICIENCY}

We now turn to our empirical case, and describe the structure and responsibilities of English local government. In 2017, local government in England consisted of 353 elected councils and bureaucracies providing services, regulation and infrastructure, directly or through commissioned third parties, within a defined locale. (Policy on local government is devolved in Scotland, Wales and Northern Ireland, and these councils are excluded below.) In the 2016-17 financial year, almost one quarter of all public expenditure in England was channelled through local authorities (Local Government Information Unit, 2017), which collectively employed a workforce exceeding one million FTE (Office for National Statistics, 
2017). Councils vary in numerous respects, but each belongs to one of five types which largely predict its service portfolio and geographic attributes.

"District councils" (currently totalling 201) and "county councils" (27) co-exist in those predominantly rural parts of the country that still operate a two-tier system of local government. Up to twelve districts sit within each county boundary. Although there is no hierarchical relation between the upper and lower tiers, counties have far larger responsibilities, including education and social care. In the mid-1990s and again in the late 2000s, this two-tier system was replaced in some areas by single-tier "unitary" authorities (56) - the third council type. These combine the functions of districts and counties, aiming to improve coordination and efficiency. Similarly, the fourth and fifth council types largely mirror the responsibilities of unitary authorities, but predate them and govern in urban areas "metropolitan districts" (36) in the Midlands and the North, and "London boroughs" (33) in the capital.

In comparative perspective, English local government has several unusual features (Norton, 1994). Councils are established legislatively rather than constitutionally, have limited rights for policy initiative, and only gained a "power of general competence" in 2011 to tackle issues beyond those prescribed by statute (Lowndes \& Pratchett, 2012). They have few tax-raising powers, meaning that "there are few Western countries in which local government is more financially dependent on central government” (Wilson \& Game, 2011, p.232). Councils in England are also on average far larger in terms of population served than elsewhere (John, 2010). Stewart (2000, p.66) attributes this to a "sizism" bias in English reforms, which prioritize organizational enlargement over local identity or representation. Since the early 1990 s alone, restructuring has eliminated some 7,000 council seats. ${ }^{1}$

\footnotetext{
${ }^{1}$ Compare figures in Newman and Thornley (1997) and Local Government Information Unit (2017).
} 
One further difference concerns the degree of inter-council cooperation traditionally practised in England. Kelly (2007) writes of a "curious absence of inter-municipal cooperation" compared with Europe, and an eight-country study by Hulst and van Montford (2012) confirmed that England made little or no use of the main kinds of collaboration found on the continent. The USA, another jurisdiction to which England is traditionally likened, also employs inter-local agreements far more extensively (Hefetz \& Warner, 2012). This English exceptionalism has several explanations. As noted, the early view was that councils vigorously defended their autonomy and individual identity (Finer, 1933; Hasluck, 1936). Yet Kelly (2007) maintains that, latterly, it is central government's use of rankings and league tables that encourages competition over collaboration. Other barriers include councils' accountability to separate electorates (Travers et al., 1995, p.9); their diminishing role in providing utilities and healthcare - which are commonly delivered inter-locally elsewhere (Kelly, 2007); and their large size, which may undermine the financial case for sharing (Dixon \& Elston, 2019).

Yet English councils are far from uncollaborative in a general sense. One count in 2002 identified, conservatively, some 5,500 partnerships with non-local-government agencies (Sullivan \& Skelcher, 2002). Council-to-council collaboration in service delivery also has some precedent historically. During the inter-war years, Hasluck (1936, p.170) identified some 223 "joint boards" for isolation hospitals, 50 for water supply, and others for electricity, gas and town planning. All barring the last of these is no longer performed by local government. Abolition of the Greater London Council and six metropolitan county councils in the 1980s brought a partial renaissance in urban areas, when lower-tier London boroughs and metropolitan districts were required to maintain some county-wide services through joint working (Leach \& Game, 1991; Norris, 2001). Nonetheless, such arrangements operated far less extensively and consistently than is the case internationally. 


\section{Recent developments and research questions}

The arrival of Eric Pickles MP as Secretary of State for Local Government in 2010 under the Conservative-Liberal Democrat coalition government signalled a new era. A former council leader, one of Pickles' first decisions was to halt a series of in-progress amalgamations initiated by the previous Labour administration (Elcock, et al., 2010). Although Whitehall already encouraged councils to share administration, Pickles wanted an expansion - and austerity provided the impetus (Bello, et al., 2018). As the government implemented major spending reductions following the global financial crisis, cutting overall grants to councils by 40 per cent in real-terms over four years (Hastings et al., 2015), guidance was issued to councils that ranked shared services first among "fifty ways to save" (DCLG, 2012) There was technical support and limited financial incentives for reform, and the Chartered Institute of Public Finance and Accountancy and Local Government Association also endorsed the new approach (Cipfa, 2010; LGA, 2012). The stage was set for significant reform.

This clear departure from established methods of local public service provision in England raises a series of questions about how such a change has been implemented. Basing our analysis on the three "instrumental" drivers for collaboration identified above resources, coordination in organizations, and political goals - we focus on the following three questions:

1. Which types of councils collaborate most?

2. Do councils choose partners similar to themselves?

3. Do partnership size and political salience affect choices about collaboration?

Should "rational" explanations prove inadequate to account for the observed levels of collaboration and partner selection, we will further consider whether the desire for legitimacy provides a more widely applicable explanation. 


\section{RESEARCH METHODS}

To explore the implementation of shared service reforms, we use social network analysis (Borgatti, et al., 2018). First, to investigate whether particular types of council are more prone to collaboration, we relate multiple council-level variables pertaining to resource, organizational and political considerations to each council's centrality. In a bimodal affiliation network (that is, one containing councils and partnerships), "centrality" describes the number of partnerships to which each council belongs. Second, to understand the character of shared service partnerships, we explore how similar (or different) councils are to their partners using homophily analysis (Borgatti, et al., 2018; McPherson et al., 2001). Homophily occurs when individuals choose partners with similar characteristics; heterophily describes dissimilarity. This analysis allows us to determine the tendency towards like or unlike pairings across the whole (unimodal) network of council-council partnerships, again based on specified council characteristics determined by theory. Third, we applied the same centrality and homophily analyses to subsets of the network to explore the impact of partnership size and political salience on the results.

We chose an exploratory rather than hypothesis-driven approach for the following reasons. First, as already discussed, the literature offers mixed evidence as to the relative importance - and even sign - of many explanatory variables. Second, our interest is in collaboration across the range of local government services, while much existing research focuses on a specific shared activity.

\section{Variables and data sources}

Dependent variables are drawn from the Local Government Association's (LGA) “Shared Services Map" published in 2017, supplemented with information from the 2016 edition. This dataset contains the names of English councils participating in shared service 
arrangements. We excluded collaborations if they contained fewer than two council partners, were duplicated in the database, or were not operational in 2017.

To perform additional analyses on partnership size, political salience and intra-county loyalties, the dataset was split into four subsets. Given private-sector evidence on the uniqueness of managing two-member compared with larger alliances (García-Canal, et al., 2003), we created (i) a separate network comprising all dyadic partnerships. To test whether political salience affects collaboration decisions, we coded the dataset by whether shared activities involved frontline, back-office, or mixed functions, and created separate (ii) "programme" and (iii) "administrative" networks accordingly. Finally, to test whether intracounty loyalties matter for two-tier councils, we created (iv) a dataset containing only county and district councils, each assigned to the appropriate geographical county group.

Each dataset was initially arranged as a bimodal network of councils and partnerships. The bimodal network provided our centrality measure, which was the number of partnerships to which each council belonged. Conversion of the bimodal network to a unimodal "councilonly" network resulted in a matrix of councils linked by membership of the same partnerships, which was used as the dependent variable for the homophily analysis.

Our independent variables are taken from official statistics and documentary sources (see Table 1) for each local council area. Variables are for the year 2010 where available, as that year marked the start of the current reforms and $77 \%$ of existing partnerships began on or after that date. In terms of resource considerations, following Andrews and Boyne (2009), our measures of social need were age and ethnic diversity (calculated as Gini-Simpson indices (Jost, 2006)) and the proportion of lone-parent households. For financial health, following Jacob and Hendrick (2013), we derived measures of fiscal risk and fiscal slack. We operationalized fiscal risk as the proportion of revenue expenditure in 2010-11 derived from sources other than council tax. This reflects each council's dependence of on external 
funding such as central government grants (Andrews, 2015). For fiscal slack, we calculated unallocated financial reserves relative to revenue expenditure, again for 2010-11. In addition, to capture the initial impact of austerity, we include each council's two-year projected budget change for 2011-2013 announced by central government in 2010. This represents the anticipated funding shortfall that councils were required to plan for at the outset of austerity. ${ }^{2}$ Administrative capacity is the proportion of administrative spending within total gross expenditure (i.e. administrative intensity; see Elston \& Dixon, forthcoming).

Regarding organizational considerations, distances between councils' administrative centres were calculated from their geographical coordinates. The number of councils within a thirty-mile radius was also calculated. Each council's internal coordination burden was calculated by assuming that reported cost categories correspond to discrete departments (Andrews \& Boyne, 2014) and structural complexity was calculated as the sum of $-x_{i} \ln \left(x_{i}\right)$ where $x_{\mathrm{i}}$ is the proportion of spending in category $i$ (Jacquemin \& Berry, 1979). The urban or rural nature of the area was operationalized as population density.

For political considerations, as well as the party controlling the council in 2010 , a dichotomous variable indicates whether or not the party was Conservative or Liberal Democrat and thus reflective of the national coalition government. Electoral instability was measured by the number of times political control changed during 2008-2017, and whether the council had no overall control in 2010.

Table 1 contains our variables, data sources, and descriptive statistics.

\section{$<<<$ Table 1 here $>>>$}

\footnotetext{
${ }^{2}$ Transitional funding capped annual reductions at $8.8 \%$; but this was temporary and so we use uncapped figures.
} 


\section{Network preparation and analysis}

Analysis was performed with UCINET (Borgatti et al., 2002; Borgatti, et al., 2018) and visualisations were created with NodeXL (Smith et al., 2010). The dependence of council centrality on each explanatory variable was analysed by network regression analysis, an analogue of ordinary least-squares regression which accounts for the auto-correlation of network data (Borgatti, et al., 2018, p.157). ${ }^{3}$ Variables were transformed as described in Table 1 to improve normality and reduce skew. Homophily was assessed by multiple regression-quadrature assignment procedure (MR-QAP) (Dekker et al., 2007; Krackhardt, 1988). The dependent variable, the unimodal matrix of inter-council links, was dichotomized (i.e. took no account of multiple links between the same two councils). Similar matrices were prepared for network subsets (i)-(iv). Independent variables were matrices of absolute differences between continuous variables for each pair of councils, and dichotomous matrices $(0=$ same, $1=$ different $)$ for categorical variables.

\section{RESULTS AND DISCUSSION}

\section{Overview and maps}

In 2017, 344 (97.5\%) of English local authorities participated in a total of 338 partnerships involving at least one other council. About forty percent of partnerships provided administrative services such as human resources, legal, financial, and digital services. The rest provided frontline (public-facing) services, of which about a quarter were concerned with health and social care; about twenty percent with activities such as housing, highways, regeneration, libraries and open spaces; another twenty percent with regulation and planning; and ten percent with waste collection. The remaining twenty percent provided

\footnotetext{
${ }^{3}$ Regressions were also performed by ordinary least-squares regression in $\mathrm{R}$ to compute additional fit parameters. In practice, almost identical significance levels were obtained showing that council centrality was only weakly auto-correlated.
} 
more than one type of service, including in some cases all council services shared across two or more councils.

Partnerships contained from two to 80 councils $($ median $=2$, mean $=4)$, with individual councils belonging to between one and 33 partnerships (median $=3$, mean $=4$ ). EM LawShare was by far the largest (with 80 members), followed by North West Legal Consortium (33) and London Highways Alliance (33). Rutland unitary authority belonged to the most partnerships (33), followed by Leicestershire county council (22), and district councils Redditch (21) and Bromsgrove (20), which mainly partnered with each other. ${ }^{4}$ Overall, sharing services produced 5,519 links between different pairs of councils across the whole network, which is just under $9 \%$ of all possible inter-council links. We found no partnerships linking English local authorities to those in Scotland, Wales or Northern Ireland. But 56 partnerships (17\%) included public bodies other than local governments, such as health, fire, and police authorities. Those bodies are excluded from this analysis.

Of the 338 partnerships, 176 (52\%) were dyads involving just two councils; and 182 had frontline ("programme") functions, 127 were administrative, and 29 were mixed (Figure 1). (In the graphs and analysis that follows, mixed partnerships are included in both the programme and administrative datasets.) Frontline services thus occupy the larger part of the network; although, relative to the volume of administrative support actually performed in councils, back-office work is significantly over-represented.

Programme and administrative partnerships had a similar proportion of dyads and a similar range of sizes. But the geographical distance between partnering councils differed between dyads and the whole dataset, and between frontline and back-office services. As shown in Figures 2a and $2 \mathrm{~b}$ and Table 2, partners were closer together in dyads than in all

\footnotetext{
${ }^{4}$ These are counts of partnerships rather than activities. Some partnerships cover several (or "all") council activities, so councils that took part in only a few such partnerships might nonetheless be sharing a significant amount of activity. We did not attempt to assess the level of shared activity represented by each partnership.
} 
partnerships and closer in programme than in administrative partnerships. ${ }^{5}$ At least $80 \%$ of links in dyadic and programme partnerships were under 30 miles, compared with $41 \%$ and $33 \%$ for all partnerships and administrative partnerships, respectively. Regardless of size or type of activity, however, the distance distribution was shifted towards shorter distances than the average distance distribution of English local councils (shown by the dotted line in the figures).

\section{$<<<$ Figures 1 and 2 here $>>>$}

\section{$<<<$ Table 2 here $>>>$}

\section{Council centrality and partnership homophily}

The results of the centrality and homophily tests on the network containing partnerships of all sizes and types of activity are shown in the first column of Tables 3 and 4 . Since council type co-varies with a number of variables, this was controlled for when assessing the relationship of centrality with the other variables. Several council characteristics also vary systematically by region so both region and council type were controlled when assessing homophily on other variables. Finally, although guided by theory, there remains a wide range of "researcher degrees of freedom" in selecting variables and network-analytic techniques. Therefore, following guidelines in Simmons et al. (2011) for exploratory analyses, we report all of the analyses performed.

\footnotetext{
$<<<$ Tables 3 and 4 here $>>>$
}

\footnotetext{
${ }^{5}$ These distributions are dominated by the larger partnerships. For example, the 80 partners of EM LawShare contribute 3160 inter-council links to the whole and the administrative distributions, or over half of all unique inter-council links in the whole network.
} 
As Table 3 indicates, resource considerations showed little relationship with propensity to collaborate. Only ethnic diversity showed a weak negative relationship. Given the marketing of shared services as a cost-reduction mechanism, the non-significance of the financial health measures is surprising. And despite fairly consistent international evidence of inter-local collaboration substituting for amalgamations and being used to address diseconomies in small jurisdictions, neither population nor prior listing as a candidate for amalgamation predicted shared services adoption. Administrative capacity was also nonsignificant.

However, as described in Table 4, resource similarity was associated with partner selection (homophily) for the variables ethnic diversity, age diversity, external income ratio, and financial reserves. Councils measuring similarly on these indicators of social need and financial health showed some tendency to work together, although these variables did not add a great deal of explanatory power to the model containing region, council type and proximity only.

Among the organizational variables, only council type was significantly related to collaboration (Table 3). Metropolitan districts partnered less than others, despite being legally required to cooperate since the 1980s (Leach \& Game, 1991). Neither opportunities for collaboration within a thirty-mile radius, nor internal coordination burden, predicted collaboration.

Yet, substantial homophily was demonstrated for organizational variables, with region, ${ }^{6}$ proximity, and council type each remaining significant when tested with the others (Table 4). The geographic relationships can be seen in Figure 1. Intra-regional partnerships are much more common than expected from proximity alone. To investigate whether this

\footnotetext{
${ }^{6}$ As council type "London borough" is identical to region "London," homophily based on region or council type cannot be distinguished for London councils.
} 
strong regional preference extends to the two-tier county system, a dataset containing only county and district councils (subset iv) was analysed. Membership of the same county group was a highly significant predictor, even after controlling for region and distance (data not shown). Among the remaining organizational variables, only population density contributed a slight additional homophily.

Contrary to expectations, political control, alignment with the national government, and electoral stability were not associated with council centrality. When tested alone, councils did seem to partner on the basis of political similarities, consistent with international evidence. But politics varies greatly between regions. The North East, for instance, had no Conservative councils in 2010, while the South West had no Labour councils. Thus, political homophily disappeared when region was accounted for; indeed, slight heterophily was shown. Given the strong correlation between region and politics, it is not possible to disentangle these effects fully, and politics may contribute to the observed regional homophily.

\section{The impact of partnership size and political salience}

To explore whether size of partnerships or political salience of the shared activities make a difference beyond our earlier observation that two-member and programmatic partnerships are arranged at markedly shorter distances (Table 2 and Figures $2 \mathrm{a}$ and $2 \mathrm{~b}$ ), we repeated the above centrality and homophily analyses on network subsets (i-iii). Results are reported in the remaining columns of Tables 3 and 4 .

Resource considerations again showed few correlations with centrality for any size or function of partnership. Dyadic and administrative partnerships had a slight positive association with budget change at the outset of austerity: smaller projected cuts were associated with slightly more partnerships of these types. But no other financial indicators were significant. For programme partnerships, ethnic diversity showed a weak negative 
relationship. As before, resource similarity was significant for partner choice on several variables. External income ratio showed homophily for all partnership types, while homophily in administrative intensity and financial reserves was found for both dyadic and programme partnerships. Similarity in projected budget cuts was not significant for any partnership type. Programme partnerships, uniquely, showed heterophily for two social-need variables (proportion of lone parent households and age diversity), in contrast to administrative partnerships (and the whole network) which showed the expected homophily for these variables.

Organizational considerations were generally consistent across network subsets. Metropolitan districts still had the lowest partnering activity of the five council types across all partnership types, although not significantly so for programme partnerships. District and county councils were most likely to share administrative services. Regions varied somewhat, with councils in the East of England most likely to join administrative partnerships, while those in London, the North East, and the North West joined more programme partnerships. Councils with lower structural complexity tended to join more administrative partnerships. Partnerships of all types displayed similarly strong regional and distance homophily, and council type homophily was significant for all except administrative partnerships.

Political considerations remained generally unimportant. Other than, as noted, administrative shared services being significantly over-represented in the network as a whole relative to the proportion of council activities that are in fact administrative, the greater political salience of frontline activities appears not to affect collaboration decisions. Both administrative and programme partnerships were unrelated to political control, stability or alignment with the national government, either in propensity to collaborate or choice of partners. Slight heterophily of political control was again demonstrated for programme partnerships specifically. 
Overall, then, we found similar patterns in the subsets as for the whole network.

This analysis has a number of limitations. The LGA shared services dataset is compiled from a self-reported survey of council officials and does not claim the status of official statistics. Nevertheless, almost all councils are represented. As noted, we record only the presence or absence of partnerships and do not attempt to assess the amount of shared activity that each represents. And, as the dataset reports partnerships operational in 2017, this is necessarily a cross-sectional study.

\section{DISCUSSION}

To summarize, propensity to collaborate is slightly explained by council type. Metropolitan districts collaborate least out of the five council types, reversing the position immediately following the abolition of metropolitan county councils in the 1980s (Travers, et al., 1995, p.1). But the remainder of our centrality model proved inadequate. Even characteristics that predict the value that a council should derive from inter-organizational working, such as low population size or precarious financial circumstances, were non-significant. By contrast, partnership composition was more predictable. Being in the same region, county (where applicable) and council type, as well as proximity, help explain partner selection, as do, to a lesser extent, comparability in certain demographic and financial characteristics. Notably, politics did not add explanatory power once region was accounted for. We also observed that councils manage two-member and programme partnerships differently than multi-member and administrative arrangements, favouring partner proximity. But splitting the data along these lines and re-testing for centrality predictors and homophily provided little additional explanatory value.

The pursuit of legitimacy provides an alternative account of public service collaborations that lack "instrumental" - that is, goal- or efficiency-related - explanation 
(Dickinson \& Sullivan, 2014; Jacobsen, 2015; Rodríguez, et al., 2007). To evaluate our results on that basis, we draw on "organizational institutionalism" - a body of theory that seeks to explain how societal norms and values come to be reflected in organizational decision-making. According to this perspective, organizations strive to achieve legitimacy among valued stakeholders in order to secure resources from the environment and autonomy from oversight authorities (Meyer \& Rowan, 1977). Legitimacy means "a generalized perception ... that the actions of an entity are desirable, proper, or appropriate within some socially constructed system of norms, values, beliefs, and definitions” (Suchman, 1995, p.574). It is attained, firstly, by demonstrating the quality of an organization's outputs; and, secondly, by indicating that values and norms were respected and reflected during production processes. Consequently, organizations seek high technical performance while at the same time abiding by "theories of production that are ingrained in the public imagination and legitimated by the educational system, the legal and political system, and professional bodies" (Bromley \& Powell, 2012, p.487). These "approved" ideas include the "prevailing policy discourse that privileges 'collaboration' above other forms of organization (such as bureaucracy or marketization)" (Skelcher \& Sullivan, 2008, p.760). The result, as Skelcher and Sullivan continue, is "powerful institutional templates ... to which organizations then adapt."

The recent literature on legitimacy-inspired collaborative public management has been predominantly qualitative and/or conceptual in focus, and so has yet to identify quantitative empirical markers for detecting this alternative non-instrumental basis for collaboration. One important signifier used in institutional research is the failure to explain decisions by other, more "rational" criteria. Longitudinal studies of reform diffusion within a population of organizations regard any gradual weakening in the predictability of reform adoption according to relevant characteristics as signifying a decline in instrumental decision- 
making and rising concern for “appropriateness" (Tolbert \& Zucker, 1983). As Scott (2014, p.203) explains:

"[Initial] adoption of the practice by organizations represents a choice on their part that can reflect their varying needs or interests. [Over time,] normative and cultural pressures mount to the point where adoption becomes less of a choice.... Differences among individual organizations are of less consequence ... [T] he logic of action has shifted from one of instrumentality to appropriateness ... so that it is increasingly in the interest of all to adopt the practice. Not to do so would be regarded as deviant, inattentive, or behind the times, resulting in a loss of legitimacy...."

Although our study is not longitudinal, English local government was far behind comparator jurisdictions in adopting inter-local collaboration (Hulst \& van Montfort, 2012; Kelly, 2007), and we have demonstrated that many "instrumental" causes of inter-local cooperation in other contexts fail to explain the English reforms. The pursuit of legitimacy is indicated.

A further sign that legitimacy is affecting collaboration derives from the tension that frequently exists between efficient and legitimate choices. As Meyer and Rowan (1977, pp.340-341) explain: "Conformity to institutionalized rules often conflicts sharply with efficiency criteria and, conversely, to coordinate and control activity in order to promote efficiency undermines an organization's ceremonial conformity and sacrifices its support and legitimacy." This trade-off requires that organizations take measures that reduce the costs of complying with culturally-appropriate but technically-inefficient templates (Oliver, 1991). Thus, "damage-limitation" measures by organizations would thus provide further evidence that legitimacy is affecting decision-making.

In the case of inter-council collaboration in England, rational partner selection amid less well-founded decisions to collaborate is strongly indicative of a legitimacy-efficiency trade-off, particularly given the lack of evidence for any efficiency savings from sharing administrative services (Elston \& Dixon, forthcoming). Collaboration is a perilous strategy, exposing organizations to the risk of conflicting goals, delayed decisions, third-party failures 
and opportunism (Elston, et al., 2018; Terman et al., 2020). As Huxham and Vangen (2005, p.13) argue, collaboration is also "is a seriously resource-consuming activity so is only to be considered when the stakes are really worth pursuing." Given these risks, careful selection of collaboration partners is a sensible approach that reduces the chance that the pursuit of legitimacy will undermine organizational performance. In particular, homophily among partners reduces the difficulties of securing agreement (Alter \& Hage, 1993, p.242), while geographical proximity increases trust through familiarity and ease of monitoring. Both were observed in the data, suggesting that councils have engaged in actions to manage the downsides associated with conforming to the collaborative template demanded by the institutional environment.

\section{CONCLUSIONS}

Inter-council shared services, which have been strongly encouraged by central government since 2010, represent a significant departure for English local authorities that have traditionally sought "self-sufficiency." This article has explored how the change has been implemented using a number of data sources and techniques of social network analysis.

Our findings suggest that the main question considered by councils since 2010 has not in fact been whether to implement shared services, but how to. The large take-up of the reform irrespective of financial, organizational and political circumstances, coupled with the strong preferences for geographical proximity and homophily on region, county, council type and certain resource indicators, supports the view that collaboration has become a "default" proposition - albeit one requiring careful partner selection if the risks of this style of organization are to be managed.

Although there is growing recognition of symbolic uses of collaboration in the public sector, research to-date has mainly been conceptual and/or qualitative (Dickinson \& Sullivan, 
2014; Jacobsen, 2015; Rodríguez et al., 2007; Sullivan et al., 2013; Skelcher \& Sullivan, 2008). Interpreting our empirical findings with the aid of the institutional theory of organizations allows us to suggest two kinds of empirical marker that could be applicable to collaboration studies more widely: declining predictability of reform decisions over time, in concert with evidence of organizations implementing risk-management practices. These insights illustrate the potential value of greater engagement between scholars of collaborative public management and the institutional theory of organizations. 


\section{BIBLIOGRAPHY}

Akaike, H. (1974). A new look at the statistical model identification. IEEE Transactions on Automatic Control, 19(6), 716-723.

Alexander, E. (1995). How Organizations Act Together. Luxembourg: Gordon and Breach.

Alonso, J., Andrews, R., \& Hodgkinson, I. (2016). Institutional, ideological and political influences on local government contracting: Evidence from England. Public Administration, 94(1), 244-262.

Alter, C., \& Hage, J. (1993). Organizations Working Together. Newbury Park: Sage.

Andrews, R. (2015). Vertical consolidation and financial sustainability: evidence from English local government. Environment and Planning C: Government and Policy, 33(6), 1518-1545.

Andrews, R., \& Boyne, G. (2009). Size, structure and administrative overheads: An empirical analysis of English local authorities. Urban Studies, 46(4), 739-759.

Andrews, R., \& Boyne, G. (2014). Task complexity, organization size, and administrative intensity: the case of UK universities. Public Administration, 92(3), 656-672.

Barney, J., \& Clark, D.. (2007). Resource-Based Theory. Oxford: Oxford University Press.

Bel, G., Fageda, X., \& Mur, M. (2014). Does Cooperation Reduce Service Delivery Costs? Evidence from Residential Solid Waste Services. Journal of Public Administration Research and Theory, 24(1), 85-107.

Bel, G., \& Warner, M. (2016). Factors explaining inter-municipal cooperation in service delivery: a metaregression analysis. Journal of Economic Policy Reform, 19(2), 91-115.

Bello, B., Downe, J., Andrews, R., \& Martin, S. (2018). Does austerity drive public service innovation: Evidence from shared senior management teams in local government. Public Money \& Management, 38(2), 131-138.

Borgatti, S. P., Everett, M. G., \& Freeman, L. C. (2002). UCINET 6 for Windows. Harvard, MA: Analytic Technologies.

Borgatti, S. P., Everett, M. G., \& Johnson, J. C. (2018). Analyzing Social Networks. London: Sage.

Bromley, P., \& Powell, W. (2012). From smoke and mirrors to walking the talk: Decoupling in the contemporary world. Academy of Management Annals, 6(1), 483-530.

Carr, J., LeRoux, K., \& Shrestha, M. (2009). Institutional Ties, Transaction Costs, and External Service Production. Urban Affairs Review, 44(3), 403-427.

Chartered Institute of Public Finance \& Accountancy. (2010). Sharing the Gain. London: CIPFA.

Chisholm, D. (1989). Coordination Without Hierarchy. Berkeley: University of California Press.

Chisholm, M., \& Leach, S. (2008). Botched Business. Coleford: Douglas McLean.

Conservative Home. (2008). Eric Pickles. Retrieved January 9th, 2019, from: http://www.conservativehome.com/localgovernment/2008/12/eric-pickles-th.html

Damanpour, F. (1991). Organizational innovation: A meta-analysis of effects of determinants and moderators. Academy of Management Journal, 34(3), 555-590.

Dekker, D., Krackhardt, D., \& Snijders, T. (2007). Sensitivity of MRQAP tests to collinearity and autocorrelation conditions. Psychometrika, 72(4), 563-581. 
Department for Communities and Local Government (DCLG). (2012). 50 Ways to Save: Examples of Sensible Savings in Local Government. London: The Stationery Office.

Dickinson, H., \& Sullivan, H. (2014). Towards a general theory of collaborative performance: the importance of efficacy and agency. Public Administration, 92(1), 161-177.

Dixon, R., \& Elston, T. (2019). Should Councils Collaborate? Evaluating Shared Administration and Tax Services in English Local Government. Public Money \& Management, 39(1), 26-36.

Dooley, K. (2002). Organizational complexity. In M. Warner (Ed.), International Encyclopedia of Business and Management (pp. 5013-5022). London: Thompson Learning.

Dye, T., Liebman, C., Williams, O., \& Herman, H. (1963). Differentiation and cooperation in a metropolitan area. Midwest Journal of Political Science, 7(2), 145-155.

Eckersley, P., \& Tobin, P. (2019). The impact of austerity on policy capacity in local government. Policy \& Politics, 47(3), 455-472.

Elcock, H., Fenwick, J., \& McMillan, J. (2010). The reorganization addiction in local government: unitary councils for England. Public Money \& Management, 30(6), 331-338.

Elston, T., \& Dixon, R. (forthcoming). The effect of shared service centres on administrative intensity in English local government: A longitudinal evaluation. Journal of Public Administration Research \& Theory.

Elston, T., MacCarthaigh, M., \& Verhoest, K. (2018). Collaborative Cost-Cutting: Productive Efficiency as an Interdependency between Public Organizations. Public Management Review, 20(12), 1815-1835.

Eythórsson, G., Kettunen, P., Klausen, J., \& Sandberg, S. (2018). Reasons for inter-municipal cooperation: A comparative analysis of Finaldn, Iceland and Norway. In F. Teles \& P. Swianiewicz (Eds.), InterMunicipal Cooperation in Europe (pp. 105-129). Palgrave Macmillan.

Feiock, R. (2007). Rational choice and regional governance. Journal of Urban Affairs, 29(1), 47-63.

Ferris, J., \& Graddy, E. (1986). Contracting out: For what? With whom? Public Administration Review, 46(4), 332-344.

Finer, H. (1933). English Local Government. London: Methuen.

Gains, F., Greasley, S., John, P., \& Stoker, G. (2009). The Impact of Political Leadership on Organisational Performance: Evidence from English Urban Government. Local Government Studies, 35(1), 75-94.

García-Canal, E., Valdés-Llaneza, A., \& Ariño, A. (2003). Effectiveness of Dyadic and Multi-Party Joint Ventures. Organization Studies, 24(5), 743-770.

Gerber, E., Henry, A., \& Lubell, M. (2013). Political Homophily and Collaboration in Regional Planning Networks. American Journal of Political Science, 57(3), 598-610.

Gulati, R. (1995). Does familiarity breed trust? The implications of repeated ties for contractual choice in alliances. Academy of Management Journal, 38(1), 85-112.

Hasluck, E. L. (1936). Local Government in England. Cambridge: Cambridge University Press.

Hastings, A., Bailey, N., Gannon, M., Besemer, K., \& Bramley, G. (2015). Coping with the cuts? The management of the worst financial settlement in living memory. Local Government Studies, 41(4), 601621.

Hefetz, A., \& Warner, M. (2012). Contracting or public delivery? The importance of service, market, and management characteristics. Journal of Public Administration Research \& Theory, 22(2), 289-317. 
Hulst, J., \& van Montfort, A. (2012). Institutional features of inter-municipal cooperation: Cooperative arrangements and their national contexts. Public Policy and Administration, 27(2), 121-144.

Huxham, C., \& Vangen, S. (2005). Managing to Collaborate.

Jacob, B., \& Hendrick, R. (2013). Assessing the financial condition of local governments: what is financial condition and how is it measured? In H. Levine, J. B. Justice \& E. A. Scorsone (Eds.), Handbook of Local Government Fiscal Health. Burlington, MA: Jones and Bartlett Learning.

Jacobsen, D. (2015). Regional governance networks: Filling in or hollowing out? Scandinavian Political Studies, 38(2), 115-136.

Jacquemin, A., \& Berry, C. (1979). Entropy measure of diversification and corporate growth. Journal of Industrial Economics, 27(4), 359-369.

Joassart-Marcelli, P., \& Musso, J. (2005). Municipal service provision choices within a metropolitan area. Urban Affairs Review, 40(4), 492-519.

John, P. (2010). Larger and larger? The endless search for efficiency in the UK. In H. Baldersheim \& L. E. Rose (Eds.), Territorial Choice (pp. 101-117). Basingstoke: Palgrave Macmillan.

Jost, L. (2006). Entropy and diversity. Oikos, 113(2), 363-375.

Kelly, J. (2007). The curious absence of inter-municipal cooperation in England. Public Policy and Administration, 22(3), 319-334.

Klok, P-J., Boogers, M., Denters, B., \& Sanders, M. (2018). Inter-municipal cooperation in the Netherlands. In F. Teles \& P. Swianiewicz (Eds.), Inter-Municipal Cooperation in Europe (pp. 157-172): Palgrave Macmillan.

Krackhardt, D. (1988). Predicting with networks: Nonparametric multiple regression analysis of dyadic data. Social Networks, 10(4), 359-381.

Krueger, S., \& McGuire, M. (2005). A transaction costs explanation of interlocal government collaboration. Paper presented at the Public Management Research Conference, Los Angeles.

Kwon, S.-W., Feiock, R. C., \& Bae, J. (2014). The Roles of Regional Organizations for Interlocal Resource Exchange:Complement or Substitute? American Review of Public Administration, 44(3), 339-357.

Leach, S., \& Game, C. (1991). English metropolitan government since abolition: An evaluation of the abolition of the English metropolitan county councils. Public Administration, 69(2), 141-170.

Lee, S.-Y., \& Whitford, A. B. (2012). Assesing the effects of organizational resources on public agency performance: Evidence from the US federal government. Journal of Public Administration Research \& Theory, 23(3), 687-712.

LeRoux, K., Brandenburger, P., \& Pandey, S. (2010). Interlocal service cooperation in U.S. cities: A social network explanation. Public Administration Review, 70(2), 268-278.

LeRoux, K., \& Carr, J. (2007). Explaining local government cooperation on public works: Evidence from Michigan. Public Works Management \& Policy, 12(1), 344-358.

Local Government Association (LGA). (2012). Services Shared: Costs Spared?. London: LGA.

Local Government Information Unit. (2017). Local government facts and figures. Retrieved 27th February, 2018, from: https:/www.lgiu.org.uk/local-government-facts-and-figures/\#how-much-do-councils-spend

Lowndes, V., \& Pratchett, L. (2012). Local Governance under the coalition government: Austerity, localism and the 'big society'. Local Government Studies, 38(1), 21-40. 
Lupton, R., Gunn, J., \& Szalay, A. (1999). A modified magnitude system that produces well-behaved magnitudes, colors and errors even for low signal-to-noise ratio measurements. Astronomical Journal, 118(3), 1406-1410.

March, J., \& Simon, H. (1993). Organizations. Cambridge, Mass.,: Blackwell.

McGuire, M., \& Silva, C. (2010). The effect of problem severity, managerial and organizational capacity, and agency structure on intergovernmental collaboration: evidence from local emergency management. Public Administration Review, 70(2), 279-288.

McLaughlin, H. (2004). Partnerships: panacea or pretence? Journal of Interprofessional Care, 18(2), 103-113.

McPherson, M., Smith-Lovin, L., \& Cook, J. (2001). Birds of a feather: Homophily in social networks. Annual Review of Sociology, 27(1), 415-444.

Meyer, J., \& Rowan, B. (1977). Institutionalized organizations: Formal structure as myth and ceremony. American Journal of Sociology, 83(2), 340-363.

Morgan, D., \& Hirlinger, M. (1991). Intergovernmental service contracts: A multivariate explanation. Urban Affairs Quarterly, 27(1), 128-144.

Newman, P., \& Thornley, A. (1997). Fragmentation and centralisation in the governance of London: Influencing the policy and planning agenda. Urban Studies, 34(7), 967-988.

Norris, D. (2001). Whither metropolitan governance. Urban Affairs Review, 36(4), 532-550.

Norton, A. (1994). International Handbook of Local and Regional Governance. Aldershot: Elgar.

Office for National Statistics. (2017). Quarterly Public Sector Employment Survey (Local Government Employment, Quarter 1, 2017). from: https:/www.local.gov.uk/ons-quarterly-public-sector-employmentsurvey

Oliver, C. (1990). Determinants of interorganizational relationships: Integration and future directions. Academy of Management Review, 15(2), 241-265.

Oliver, C. (1991). Strategic responses to institutional processes. Academy of Management Review, 16(1), 145179.

Ostrom, V., Tiebout, C., \& Warren, R. (1961). The Organization of government in metropolitan areas: A theoretical inquiry. American Political Science Review, 55(04), 831-842.

Puey, E., Tejado, L., Mussons, C., \& Ferran, J. (2018). Layer upon layer: The position of inter-municipal cooperation in the Spanish quasi-federal system - the case of Catalonia. In F. Teles \& P. Swianiewicz (Eds.), Inter-Municipal Cooperation in Europe (pp. 259-277): Palgrave.

Rodríguez, C., Langley, A., Béland, F., \& Denis, J-L. (2007). Governance, power, and mandated collaboration in an interorganizational network. Administration \& Society, 39(2), 150-193.

Scott, W. (2014). Institutions and Organizations. Thousand Oaks, CA: Sage.

Shrestha, M., \& Feiock, R. (2011). Transaction cost, exchange embeddedness, and interlocal cooperation in local public goods supply. Political Research Quarterly, 64(3), 573-387.

Simmons, J., Nelson, L., \& Simonsohn, U. (2011). False-positive psychology: Undisclosed flexibility in data collection and analysis allows presenting anything as significant. Psychological Science, 22(11), 13591366.

Skelcher, C., \& Sullivan, H. (2008). Theory-driven approaches to analysing collaborative performance. Public Management Review, 10(6), 751-771. 
Smith, M., Ceni, A., Milic-Frayling, N., Shneiderman, B., Mendes Rodrigues, E., Leskovec, J., \& Dunne, C. (2010). NodeXL add-in for Excel. Social Media Research Foundation.

Song, M., Park, H., \& Jung, K. (2018). Do political similarities facilitate interlocal collaboration? Public Administration Review, 78(2), 261-269.

Steiner, R. (2003). The causes, spread and effects of intermunicipal cooperation and municipal mergers in Switzerland. Public Management Review, 5(4), 551-571.

Stewart, J. (2000). The Nature of British Local Government. Basingstoke: Macmillan.

Suchman, M. C. (1995). Managing legitimacy: Strategic and institutional approaches. Academy of Management Review, 20(3), 571-610.

Sullivan, H., \& Skelcher, C. (2002). Working Across Boundaries. Basingstoke: Palgrave Macmillan.

Sullivan, H., Williams, P., Marchington, M., \& Knight, L. (2013). Collaborative futures: discursive realignments in austere times. Public Money \& Management, 33(2), 123-130.

Teles, F., \& Swianiewicz, P. (Eds.). (2018). Inter-Municipal Cooperation in Europe. Palgrave Macmillan.

Terman, J., Feiock, R., \& Youm, J. (2020). When collaboration is risky business: The influence of collaboration risks on formal and informal collaboration. American Review of Public Administration, 50(1), 33-44.

Tolbert, P., \& Zucker, L. (1983). Institutional sources of change in the formal structure of organizations: The diffusion of civil service reform, 1880-1935. Administrative Science Quarterly, 28, 22-39.

Tomaney, J., \& Ward, N. (2000). England and the 'New Regionalism'. Regional Studies, 34(5), 471-478.

Travers, T., Biggs, S., \& Jones, G. (1995). Joint Working between Local Authorities. London: LGC Communications.

Wilson, D., \& Game, C. (2011). Local Government in the United Kingdom. Basingstoke: Palgrave Macmillan. 
Table 1. Variables, data sources and descriptive statistics for all English local authorities

\begin{tabular}{|c|c|c|c|c|c|}
\hline & Concept & Variable & Data source & $\begin{array}{l}\text { Mean } \\
\text { [count for } \\
\text { dichotomous } \\
\text { variables] }\end{array}$ & $\begin{array}{l}\text { Standard } \\
\text { deviation }\end{array}$ \\
\hline \multirow[t]{2}{*}{$\begin{array}{l}\text { Dependent } \\
\text { variables }\end{array}$} & Council centrality & $\begin{array}{l}\text { Number of partnerships joined by each council in } \\
\text { Whole dataset } \\
\text { Dyadic partnerships } \\
\text { Programme (and mixed) partnerships } \\
\text { Administrative (and mixed) partnerships } \\
\text { (arcsinh transformed (Lupton et al., 1999)) }\end{array}$ & $\begin{array}{l}\text { Derived from LGA Shared } \\
\text { Services Map dataset } 2016 \text { and } \\
2017 \text { editions }\end{array}$ & $\begin{array}{l}4.05 \\
1.00 \\
2.34 \\
1.96\end{array}$ & $\begin{array}{l}3.59 \\
2.11 \\
2.81 \\
1.67\end{array}$ \\
\hline & $\begin{array}{l}\text { Homophily or } \\
\text { heterophily }\end{array}$ & $\begin{array}{l}\text { Matrix of links between councils in } \\
\text { Whole dataset } \\
\text { Dyadic partnerships } \\
\text { Programme (and mixed) partnerships } \\
\text { Administrative (and mixed) partnerships }\end{array}$ & As above. & $\begin{array}{l}{[5519]} \\
{[106]} \\
{[1639]} \\
{[4682]}\end{array}$ & \\
\hline \multicolumn{6}{|c|}{ Independent variables } \\
\hline \multirow[t]{6}{*}{$\begin{array}{l}\text { Resource } \\
\text { considerations }\end{array}$} & Council size & Population served $(\log )[\mathrm{C}, \mathrm{H}]$ & $\begin{array}{l}\text { Office of National Statistics } \\
\text { (ONS) }\end{array}$ & 217194 & 219728 \\
\hline & & Lower-tier (district) council [C] & & {$[201]$} & \\
\hline & & $\begin{array}{l}\text { Councils considered for amalgamation in 2007-9 } \\
\text { (but which did not amalgamate) [C] }\end{array}$ & $\begin{array}{l}\text { Hansard, Electoral } \\
\text { Commission, Chisholm and } \\
\text { Leach (2008) }\end{array}$ & {$[57]$} & \\
\hline & Local conditions & $\begin{array}{l}\text { Level of deprivation, estimated as the proportion of } \\
\text { lone-parent households }[\mathrm{C}, \mathrm{H}]\end{array}$ & ONS & 0.065 & 0.017 \\
\hline & & $\begin{array}{l}\text { Age diversity of population (Gini-Simpson index) } \\
\text { (squared) }[\mathrm{C}, \mathrm{H}]\end{array}$ & ONS & 8787 & 69 \\
\hline & & $\begin{array}{l}\text { Ethnic diversity of population (Gini-Simpson } \\
\text { index) }(\log )[\mathrm{C}, \mathrm{H}]\end{array}$ & ONS & 1755 & 1757 \\
\hline
\end{tabular}




\begin{tabular}{|c|c|c|c|c|c|}
\hline & Concept & Variable & Data source & $\begin{array}{l}\text { Mean } \\
\text { [count for } \\
\text { dichotomous } \\
\text { variables] }\end{array}$ & $\begin{array}{l}\text { Standard } \\
\text { deviation }\end{array}$ \\
\hline & Financial health in 2010 & $\begin{array}{l}\text { Fiscal risk, measured as proportion of revenue } \\
\text { expenditure derived from sources other than council } \\
\operatorname{tax}[\mathrm{C}, \mathrm{H}]\end{array}$ & $\begin{array}{l}\text { Local Authority Revenue } \\
\text { Expenditure Statistics, 2010-11 }\end{array}$ & 0.64 & 0.14 \\
\hline & & $\begin{array}{l}\text { Fiscal slack, measured as unallocated financial } \\
\text { reserves relative to revenue expenditure (arcsinh) } \\
{[\mathrm{C}, \mathrm{H}]}\end{array}$ & $\begin{array}{l}\text { Local Authority Revenue } \\
\text { Expenditure Statistics, 2010-11 }\end{array}$ & 0.12 & 0.17 \\
\hline & & $\begin{array}{l}\text { Initial impact of austerity, measured as projected } \\
\text { proportional change in spending power } 2011-13 \text { [C, } \\
\text { H] }\end{array}$ & $\begin{array}{l}\text { Local Government Spending } \\
\text { Settlement 2011-2013 }\end{array}$ & -0.11 & 0.04 \\
\hline & $\begin{array}{l}\text { Administrative capacity } \\
\text { in } 2010\end{array}$ & $\begin{array}{l}\text { Administrative intensity, measured as proportion of } \\
\text { gross service expenditure spent on administration } \\
\text { (management \& support services) }(\log )[\mathrm{C}, \mathrm{H}]\end{array}$ & $\begin{array}{l}\text { Local Authority Revenue } \\
\text { Expenditure Statistics, 2010-11 }\end{array}$ & 0.25 & 0.20 \\
\hline \multirow[t]{6}{*}{$\begin{array}{l}\text { Organizational } \\
\text { considerations }\end{array}$} & Council type & $\begin{array}{l}\text { London borough, metropolitan district, unitary } \\
\text { authority, county council, district council }[\mathrm{C}, \mathrm{H}]\end{array}$ & & & \\
\hline & Location & English region (nine regions) $[\mathrm{C}, \mathrm{H}]$ & & & \\
\hline & & $\begin{array}{l}\text { Urban-rural character, estimated as population } \\
\text { density }\left(\text { persons } / \mathrm{km}^{2}\right)(\log )[\mathrm{C}, \mathrm{H}]\end{array}$ & ONS & 1616 & 2454 \\
\hline & & $\begin{array}{l}\text { Geographical distance (miles) between council } \\
\text { pairs }[\mathrm{H}] \text { and number of councils within } 30 \text { miles } \\
{[\mathrm{C}]}\end{array}$ & $\begin{array}{l}\text { LGA Shared Services Map } \\
\text { dataset }\end{array}$ & $\begin{array}{l}116 \\
25\end{array}$ & $\begin{array}{l}66 \\
20\end{array}$ \\
\hline & & $\begin{array}{l}\text { Location within the same two-tier county (county } \\
\text { and district councils only) }[\mathrm{H}]\end{array}$ & & & \\
\hline & $\begin{array}{l}\text { Internal coordination } \\
\text { burden in } 2010\end{array}$ & $\begin{array}{l}\text { Structural complexity, calculated from the } \\
\text { distribution of spending across categories as } \\
\text { described in the text }[\mathrm{C}, \mathrm{H}]\end{array}$ & $\begin{array}{l}\text { Local Authority Revenue } \\
\text { Expenditure Statistics, 2010-11 }\end{array}$ & 1.53 & 0.14 \\
\hline
\end{tabular}




\begin{tabular}{|c|c|c|c|c|c|}
\hline & Concept & Variable & Data source & $\begin{array}{l}\text { Mean } \\
\text { [count for } \\
\text { dichotomous } \\
\text { variables] }\end{array}$ & $\begin{array}{l}\text { Standard } \\
\text { deviation }\end{array}$ \\
\hline \multirow{4}{*}{$\begin{array}{l}\text { Political } \\
\text { considerations }\end{array}$} & Partisanship in 2010 & Party in control of council $[\mathrm{C}, \mathrm{H}]$ & House of Commons Library & & \\
\hline & $\begin{array}{l}\text { Alignment with national } \\
\text { government in } 2010\end{array}$ & Conservative or Lib Dem control [C] & Ibid. & {$[224]$} & \\
\hline & Political instability & $\begin{array}{l}\text { Number of changes in council control, 2008-2017 } \\
(\log )[C]\end{array}$ & Ibid., 2008-2017 & 0.71 & 0.90 \\
\hline & & No overall political control ("hung council") [C] & Ibid., 2010 & {$[73]$} & \\
\hline
\end{tabular}

[C] Variables used in centrality analysis: absolute or categorical values for each council (transformed when necessary to reduce skew). Population and household data are mid-2015 estimates; age and ethnicity are taken from the 2011 UK-wide census.

$[\mathrm{H}]$ Variables used in homophily-heterophily analysis: for continuous variables, a matrix of absolute differences between untransformed values for each pair of councils; and for categorical variables, a matrix showing same $=0$ or different $=1$, for each pair of councils. 
Table 2 Descriptive summary of partnerships

\begin{tabular}{lrrrrr} 
& $\begin{array}{r}\text { All } \\
\text { partnerships }\end{array}$ & Dyadic & Programme $^{\text {a }}$ & Administrative $^{\text {b }}$ & $\begin{array}{r}\text { All } \\
\text { councils }\end{array}$ \\
\hline $\begin{array}{l}\text { Number of participating } \\
\text { councils }\end{array}$ & 344 & 148 & 281 & 303 & 353 \\
$\begin{array}{l}\text { Number of partnerships } \\
\begin{array}{l}\text { Percentage of possible inter- } \\
\text { council links ("density” of } \\
\text { unimodal network) }\end{array}\end{array} \quad 338$ & 176 & 211 & 156 & na \\
$\begin{array}{l}\text { Median inter-council } \\
\text { distance (miles) }\end{array}$ & $8.9 \%$ & $0.2 \%$ & $2.6 \%$ & $7.6 \%$ & na \\
$\begin{array}{l}\text { Percentage of distances } \\
\text { under 30 miles }\end{array}$ & 36.8 & 14.2 & 15.7 & 42.2 & 107.7 \\
\hline
\end{tabular}

a Programme partnerships provide public-facing services in the following broad categories: health and social care (27\%); housing, highways, regeneration, and culture (20\%); regulation and planning (20\%); waste management (11\%); and cross-council services (22\%).

${ }^{\mathrm{b}}$ Administrative partnerships provide human resources, legal, digital, procurement, property-management and/or financial services. Many partnerships provide a variety of services so the proportions were not calculated. 
Table 3. Factors associated with council centrality (number of partnerships joined).

Variable

Council type (district councils omitted)
Type of partnership

\begin{tabular}{llll} 
All & Dyadic & Programme & Administrative \\
\hline $\mathrm{aR}^{2}=0.02$, & $\mathrm{aR}^{2}=0.04$, & $\mathrm{aR}^{2}=0.03$ & $\mathrm{aR}^{2}=0.11$, \\
Metropolitan & Metropolitan & & Metropolitan \\
districts $-\mathrm{ve}$ & districts $-\mathrm{ve}$ & & $\begin{array}{l}\text { districts, London } \\
\text { boroughs, unitary }\end{array}$ \\
& & & authorities -ve
\end{tabular}

Akaike information

criterion (AIC)

827

876

603

Region (East of England

omitted)

$\mathrm{aR}^{2}=0.03$

$\mathrm{aR}^{2}=0.02$

$\mathrm{aR}^{2}=0.11$ London,

North East, and

$\mathrm{aR}^{2}=0.15$

North West +ve

all regions $-\mathrm{ve}$

848

591

AIC

742

836

The following variables were each tested separately while controlling for council type

\section{Resource considerations}

Population

Restructuring candidate

Lone parent households

Age diversity

Ethnic diversity

$\mathrm{aR}^{2}=0.04,-\mathrm{ve}$,

$\mathrm{aR}^{2}=0.05,-\mathrm{ve}$,

External income ratio

Financial reserves

Projected budget change

$\mathrm{aR}^{2}=0.06,+\mathrm{ve}$,

$\mathrm{aR}^{2}=0.13,+\mathrm{ve}$,

Administrative intensity

Organizational considerations

Population density

Neighbours in 30 miles

$\mathrm{aR}^{2}=0.05,-\mathrm{ve}$,

Structural complexity

$\mathrm{aR}^{2}=0.13,-\mathrm{ve}$,

\section{Political considerations}

Political control

Aligned nationally

No overall control

Political changes 2008-17

Notes: Fit improvement was judged by the difference in Akaike information criterion (Akaike, 1974) between a model including council type only and a model including council type and the tested variable. Where tested variables improved the fit (AIC fell by at least 6) and coefficients were significant at the $\mathrm{p}<0.01$ level (uncorrected for multiple comparisons), adjusted $\mathrm{R}^{2}\left(\mathrm{aR}^{2}\right)$ and the sign of the coefficient are shown. 
Table 4. Factors associated with homophily or heterophily. Adjusted $R^{2}\left(a R^{2}\right)$ and standardised coefficients (Std coeff) are shown where $p<0.01$, uncorrected for multiple comparisons. Negative coefficients indicate homophily and positive coefficients (shaded cells) indicate heterophily.

\begin{tabular}{|c|c|c|c|c|c|c|c|c|}
\hline \multirow{3}{*}{ Variable } & \multicolumn{8}{|c|}{ Type of partnership } \\
\hline & \multicolumn{2}{|l|}{ All } & \multicolumn{2}{|l|}{ Dyadic } & \multicolumn{2}{|c|}{ Programme } & \multicolumn{2}{|c|}{ Administrative } \\
\hline & $\mathrm{aR}^{2}$ & Std coeff & $\mathrm{aR}^{2}$ & Std coeff & $\mathrm{aR}^{2}$ & Std coeff & $\mathrm{aR}^{2}$ & Std coeff \\
\hline Council type & 0.01 & -0.11 & 0.001 & -0.03 & 0.02 & -0.04 & 0.01 & -0.07 \\
\hline Region & 0.20 & -0.45 & 0.009 & -0.09 & 0.17 & -0.41 & 0.13 & -0.35 \\
\hline Geographical distance & 0.12 & -0.34 & 0.004 & -0.07 & 0.06 & -0.24 & 0.09 & -0.30 \\
\hline $\begin{array}{l}\text { All three variables tested } \\
\text { together (coefficients } \\
\text { ordered as council type } † \text {; } \\
\text { region; distance) }\end{array}$ & 0.23 & $\begin{array}{l}-0.04 \\
-0.36 \\
-0.19\end{array}$ & 0.009 & $\begin{array}{r}-0.01 \\
-0.08 \\
-0.02\end{array}$ & 0.18 & $\begin{array}{r}-0.07 \\
-0.36 \\
-0.08\end{array}$ & 0.15 & $\begin{array}{l}-0.02 \\
-0.28 \\
-0.18\end{array}$ \\
\hline \multicolumn{9}{|c|}{ The following variables were each tested separately while controlling for homophily in council type, region, and distance } \\
\hline \multicolumn{9}{|l|}{ Population } \\
\hline Lone parent households & & & & & 0.18 & 0.04 & 0.16 & -0.04 \\
\hline Age diversity & 0.24 & -0.06 & 0.010 & -0.01 & 0.18 & 0.04 & 0.16 & -0.10 \\
\hline Ethnic diversity & 0.23 & -0.04 & & & & & 0.16 & -0.04 \\
\hline External income ratio & 0.24 & -0.06 & 0.010 & -0.01 & 0.18 & -0.04 & 0.16 & -0.06 \\
\hline Financial reserves & 0.23 & -0.04 & 0.010 & -0.01 & 0.18 & -0.07 & & \\
\hline \multicolumn{9}{|l|}{ Projected budget changes } \\
\hline Administrative intensity & & & 0.010 & -0.01 & 0.18 & -0.07 & & \\
\hline \multicolumn{9}{|c|}{ Organizational considerations } \\
\hline Population density & 0.23 & -0.04 & & & 0.18 & 0.06 & 0.16 & -0.09 \\
\hline \multicolumn{9}{|l|}{ Structural complexity } \\
\hline \multicolumn{9}{|l|}{ Political considerations } \\
\hline Political control & 0.23 & 0.03 & & & 0.18 & 0.04 & & \\
\hline
\end{tabular}

$\dagger$ For back-office partnerships, council type was non-significant when tested with other variables 


\section{Figures}

Figure 1. Map of shared services in England. Local authorities are shown at the approximate position of their administrative centres (Isles of Scilly are shown inset). Key: unitary authority (black disc), metropolitan district (grey circle), London borough (dark grey disc), county council (dark grey diamond), district council (light grey disc). Grey lines link each partnership (black triangles) to its member councils. Outline map obtained from https://d-maps.com/m/europa/uk/angleterre/angleterre04.pdf

\section{Programme partnerships}

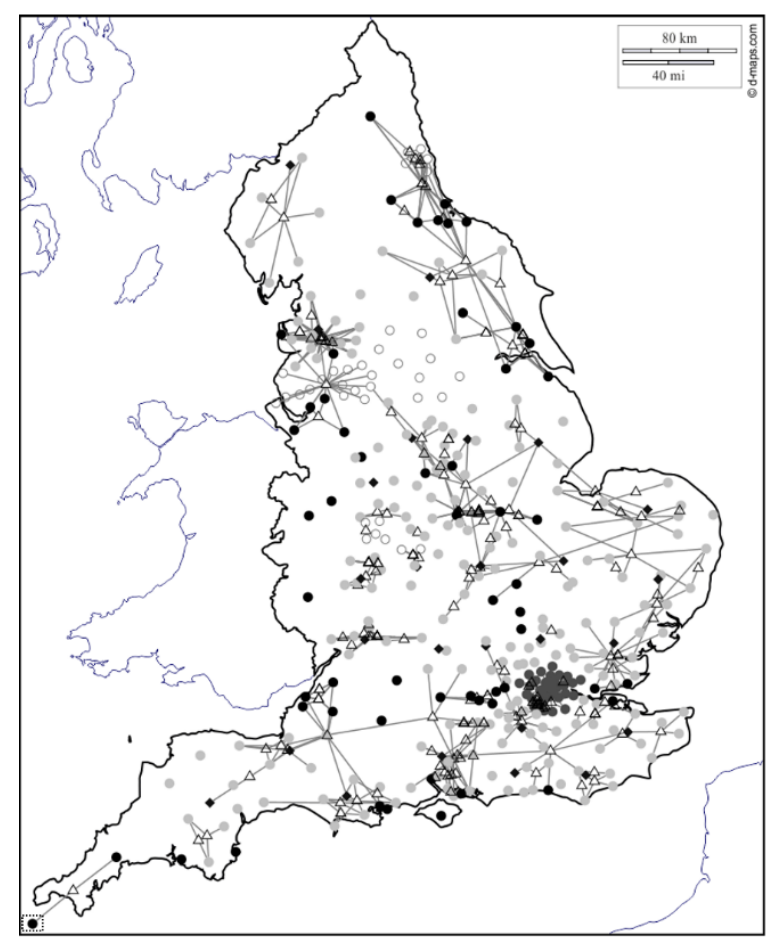

Administrative partnerships

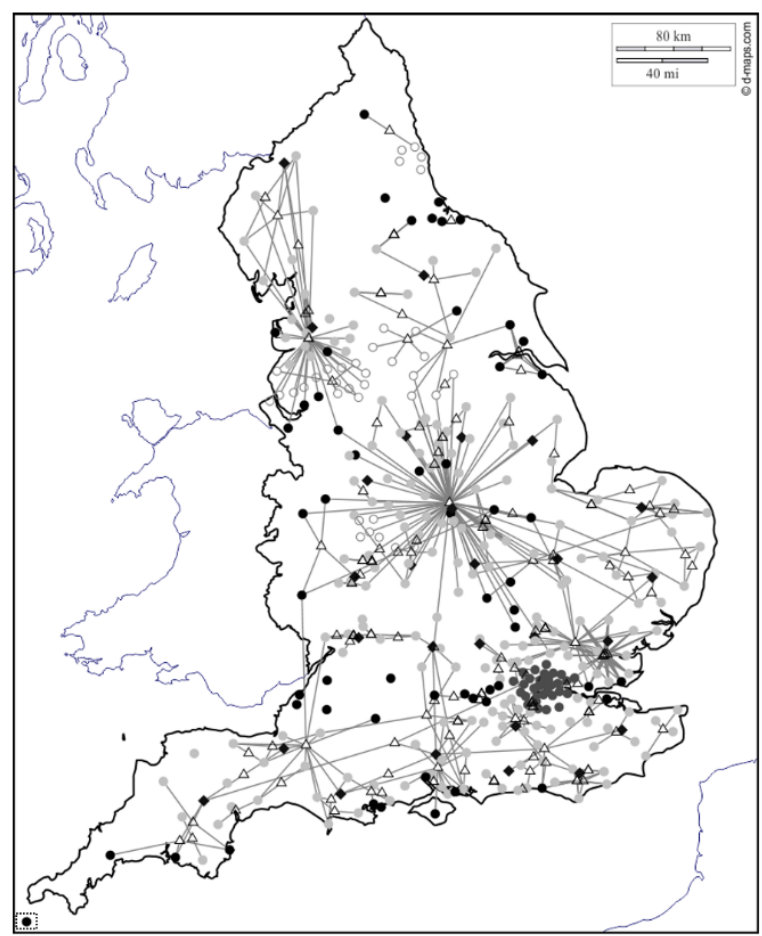


Figure 2: Frequency distributions of distances between partnering councils (measured as a straight line between their administrative centres). $2 \mathrm{a}$ : all partnerships and dyadic (2-member) partnerships; $2 \mathrm{~b}$ : programme and administrative partnerships. The dotted line shows the distribution of distances between all possible pairs of English councils.

$2 a$

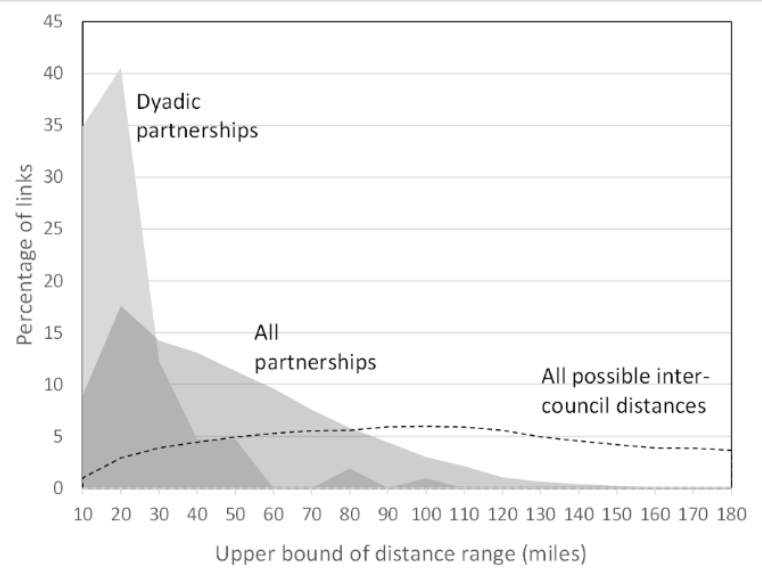

$2 b$

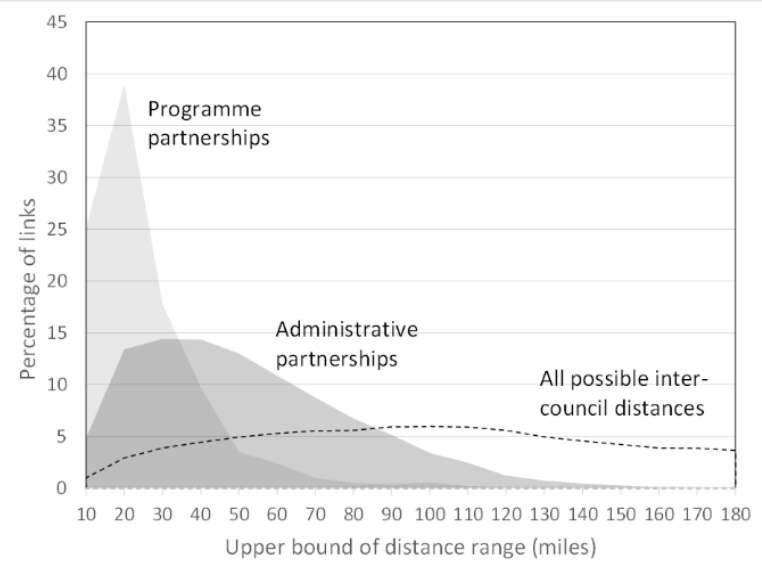

